TEME, г. XLV, бр. 1, јануар - март 2021, стр. 19-32

\begin{tabular}{lr}
\hline \hline Претходно саопштење & https://doi.org/10.22190/TEME200509002S \\
Примљено: 5. 9. 2020. & UDK 378:371.12]:004.738.4
\end{tabular}

Ревидирана верзија: 7. 2. 2021.

Одобрено за штампу: 26. 2. 2021.

\title{
THE READINESS OF TEACHERS FOR IMPLEMENTING INFORMATION AND COMMUNICATION TECHNOLOGY IN SERBIAN HIGHER EDUCATION INSTITUTIONS
}

\author{
Danijela Šćepanovići ${ }^{*}$, Isidora Korać2 \\ Bojan Lazarević ${ }^{3}$ \\ ${ }^{1}$ Ministry of Education, Science and Technological Development, \\ Belgrade, Serbia \\ ${ }^{2}$ College of Professional Studies for Educators and Business Informatics \\ Sirmium, Sremska Mitrovica, Serbia \\ ${ }^{3}$ College of Education, University of Florida, Gainesville, Florida, USA
}

\begin{abstract}
Recent advancements of Information and Communication Technology (ICT) and the increased use of ICT related services in the field of online learning offer a range of possibilities, but also pose a challenge for administration in the institutions of higher education. A plethora of official documents dealing with the analysis of how ICT is applied in teaching practice indicate the existing gap in teachers' digital competencies for its implementation. The paper discusses teachers' perceptions of various aspects related to the use ICT in teaching at higher education institutions, as well as their needs for professional development in this area. The study included 211 teachers employed in higher education institutions within the Universities of Belgrade, Novi Sad, Kragujevac, Novi Pazar, and Nis. Considering the purpose of this research, the authors designed a measuring instrument comprised of open and closed-ended questions. The study results indicate that teachers recognize the need for integrating ICT in instruction, while their perception of the level of access to ICT learning resources varies depending on the given technology or ICT related services. It is identified that the practical integration of ICT in the classroom still remains at an intermediate or relatively low level. With regard to teacher perception of the intensity of utilizing different software applications in direct instruction, the overall results demonstrate that basic business/productivity application packages such as MS Office are the predominant form of software used in the classroom, followed by Learning Management Systems (LMS). Finally, it is worth noting that teachers' perception of available professional development opportunities is considerably low, but coupled with a relatively high personal interest in participating in professional development activities.
\end{abstract}

Key words: information and communication technology, teachers, higher education, in-service teacher training, instruction.

\footnotetext{
* Аутор за кореспонденцију: Данијела Шћепановић, Министарство просвете, науке и технолошког развоја Републике Србије, Немањина 22, 11000 Београд, Србија, danijela.scepanovic@mpn.gov.rs
} 


\title{
СПРЕМНОСТ НАСТАВНИКА ЗА ПРИМЕНУ ИНФОРМАЦИОНО-КОМУНИКАЦИОНИХ ТЕХНОЛОГИЈА У ИНСТИТУЦИЈАМА ВИСОКОГ ОБРАЗОВАЫА
}

\author{
Апстракт
}

Развој информационих и комуникационих технологија (ИКТ) и повећан обим услуга у области отвореног онлајн-образовања нуде низ могућности, али и представљају изазов за високо образовање. Бројни званични документи из области образовања који се баве анализом начина на које се ИКТ примењује у наставној пракси указују на недовољну развијеност дигиталних компетенција наставника. У раду се разматрају различити ставови наставника у вези са применом ИКТ-а у настави у установама високог образовања, као и потребе за стручним усавршавањем у овој области. У истраживању је учествовало 211 наставника запослених у установама високог образовања на универзитетима у Београду, Новом Саду, Крагујевцу, Новом Пазару и Нишу. У складу са сврхом истраживања, осмишљен је упитник са питањима отвореног и затвореног типа. Налази истраживања указују на то да наставници препознају потребу примене ИКТ-а у наставном процесу, док је њихова процена приступа ИКТ наставним материјалима различита у зависности од приступа технологији и ИКТ услугама. Утврђено је да је ниво практичне примене ИКТ-а у учионици и даље осредњи или релативно низак. Када је у питању употреба софтверских решења у настави, налази указују на то да преовладава примена основних софтверских решења као што је MS Office, а потом примена система за управљање учењем. Важно је истаћи да наставници сматрају да немају довољно прилика за учешће у програмима стручног усавршавања из ове области, а да су, са друге стране, веома заинтересовани да учествују у њима.

Кључне речи: информационо-комуникационе технологије, наставници, високо образовање, стручно усавршавање наставника, настава.

\section{INTRODUCTION}

Bearing in mind the trends that shape modern education, among which information revolution dominates, it can be pointed out that one of the main challenges in the higher education system is to increase its capacity for the implementation of ICT in order to improve the quality of the learning process (Commission of the European Communities, 2008). In the period between 2008 and 2011, the volume of Internet traffic, measured in bytes, increased more than threefold (OECD, 2015) in European countries. According to the results of the OECD PISA 2012 survey in the Republic of Serbia Internet access for 15-year-olds increased between 2009 and 2012 more than $25 \%$, and more than $30 \%$ of students accessed the Internet for the first time after they turned 13. The percentage of students in Serbia who reported having at least one computer at home in 2012 was higher than the OECD average (OECD, 2015).

According to Ferrari (2013), it is expected that prospective $21^{\text {st }}$ century students tend to use ICT therefore, they should have the opportunity 
to use learning technologies in the institutions of higher education. Efficient use of ICT in teaching involves not only the provision of the necessary computer equipment, but also the examination of user needs, permanent technical support, and specific competences of teachers. Competence can be defined as a dynamic combination of knowledge, skills and attitudes that enable individuals to actively and effectively operate in a particular situation (Pantić \& Wubbels, 2010). The digital competence of teachers is one of the eight key competences needed for life in a knowledge-based society (European Commission, 2010, 2013). In order to successfully apply ICT in instruction, teachers are expected to be proficient in using computer applications (word processing, spreadsheet, database, storage and handling of information and the understanding of the opportunities and potential risks of the Internet and communication via electronic media) for the purpose of sharing and managing data, networking and setting up collaborative environments for learning and research (Haggard et al., 2013). Required skills include the ability to search, collect and process information, and to use it in a critical and systematic way, assessing the relevance and distinguishing reliable information from invalid content while recognizing the connections (The European Parliament and the Council of the European Union, 2006).

The OECD study focused on the analysis of current practices in using ICT in instruction, suggests that education systems are not yet ready to exploit the potential that technology can offer. Similar findings were obtained with regard to a number of specific institutions of higher education. The report related to its modernization (High Level Group on the Modernisation of Higher Education, 2013) emphasizes that the application of ICT in the classroom poses new challenges when it comes to teacher competencies needed for performing efficient instruction.

"Gaps in the digital skills of both teachers and students, difficulties in locating high-quality digital learning resources from among a plethora of poor quality ones, a lack of clarity on the learning goals, and insufficient pedagogical preparation for blending technology meaningfully into lessons and curricula, create a wedge between expectations and reality. If these challenges are not addressed as part of the technology plans of schools and education ministries, technology may do more harm than good to the teacher student interactions that underpin deep conceptual understanding and higher-order thinking." (OECD, 2015, p. 190)

Furthermore, the European Commission in the report entitled Opening up Education: Innovative Teaching and Learning for All Through New Technologies and Open Educational Resources pointed out that all educational institutions should consider their organizational strategies in order to improve their capacity and teacher competences for the implementation of ICT (European Commission, 2013). Additionally, the document Europe 2020: A Strategy for Smart, Sustainable and Inclusive Growth (European Commission, 
2010) recommends that the Member States should make distance learning a key element of national education policies on the path towards the modernization of the education system, with particular emphasis on reforms of curricula, the assessment of learning outcomes and the professional development of teachers. There are other documents proposed by the European Commission concerning education that emphasize the importance of teacher digital competence by providing the framework for their professional development in this area. For example, Transforming Education: The Power of ICT Policies; or DIGCOMP: A Framework for Developing and Understanding Digital Competence in Europe and Others.

A body of research suggests that the integration of ICT in instruction transforms higher education into a more effective learning environment (Cepni, Tas \& Kose, 2006; Aloraini, 2012; Šćepanović, Marjanović i Radišić, 2016; Mayer, 2017). Both teachers and students recognized that the implementation of ICT facilitates effective communication, collaborative learning, and opportunities for creating virtual learning groups (Cairncross \& Mannion, 2001). Additionally, it is highlighted that ICT contributes to the process of enhancing the quality of instruction since it introduces innovative instructional methods and strategies, stimulate students' motivation and commitment to the learning process (Moreno \& Mayer, 2000a; Moreno \& Mayer, 2000b; Mayer, 2017). However, some authors highlight that a significant number of learners utilize minimal affordances of ICT since there is uncertainty around data protection, etiquette, and digital competences (Sipos et al., 2015, Balazs, 2017). On the other hand, Balazs (2017) suggests that there are generational differences in using ICT in the process of learning. Students are more inclined to use various Web tools, while teachers primarily use basic computer programs without investing significant efforts in utilizing specifics software packages. The author concluded that this practice is perceived as a barrier to conducting an effective instructional process.

To shed some additional light on this rather complex issue, we have assessed the availability of resources and the levels of educational technology in teaching at higher education institutions in the Republic of

Serbia. Research presented in this paper aims to examine the attitudes of teachers regarding the application of ICT in teaching at higher education institutions and their in-service training needs as it was part of the broader research for a doctoral thesis (Šćepanović, 2016).

\section{METHODS}

Study Design, Purpose, and Research Questions. The overall researchers' intention was to identify and describe a number of variables associated with teachers use and integration of ICT in the Serbian system of higher education. Additionally, the researchers' sought to determine the extent of the relationship between an array of specific variables to 
obtain an in-depth understanding of the process relevant to the use of ICT in the state educational system. Therefore, the study design utilizes the descriptive and correlation-based approach with elements of surveying.

The following research questions were addressed: 1) What is the teachers' perception of the access level to ICT resources within their educational institutions? 2) What educational technologies and software do teachers use in instruction?; 3) What is the teachers' perception of professional development and participation in ICT related developmental projects?

Population and Sample. The researchers selected ten institutions of higher education encompassing all major academic centers in the Republic of Serbia (institutions within the Universities of Belgrade, Novi Sad, Kragujevac, Novi Pazar, and Nis) for the study. The institutions were selected on the basis of their previous participation in projects related to educational technology either previously financed through the European Union Tempus program, including programs implemented by the non-governmental organizations, such as World University Service Austria. Another criterion was based on the existence of organizational units or departments dedicated to distance education development (elearning, online teaching). This criterion was intentionally imposed, assuming that the existence of such units or departments indicate that the institution is interested in the integration of ICT in education and complimentary investments in this area. Therefore, the target population for this study were the educators who have participated in a variety of European Tempus programs since 2010. The purposive sampling technique was utilized in this research. Considering the study questions and limitations, this type of non-probability sample was an adequate selection.

Specifically, the sample consists of 211 teachers employed at higher education institutions, $51.2 \%$ of which were male and $48.5 \%$ female. Respondents were divided into age categories, where most respondents are in the category of 35-44 years (37.4\%), while the second category respondents' age were between 22-34 years (29.4\%) The majority of respondents hold the rank of assistant professor (31.3\%) and teaching fellow (29.4\%), while there were $15.6 \%$ of respondents with full-time professorship appointment. Other faculty ranks were represented by $9 \%$ of the total study subjects. (Table 1).

Table 1. The distribution of the sample according to the teaching position

\begin{tabular}{lcc}
\hline Teaching position & $\mathrm{N}$ & $\%$ \\
\hline Teaching Fellow & 62 & 29.4 \\
Assistant Professor & 66 & 31.3 \\
Associate Professor & 31 & 14.7 \\
Professor & 33 & 15.6 \\
Other Ranks (Teaching Associate, Lecturer \& VET Teacher) & 19 & 9 \\
\hline Total & 211 & 100.0 \\
\hline
\end{tabular}


As for the number of years of service in the institutions of higher education, the majority of faculty with a rank of assistant professor have 10-20 years of service (62.1\%), while an equal number of Teaching Fellows at institutions of higher education have 1-5 and 5-10 years of service $(40.3 \%)$. Finally, the number of respondents $(78.8 \%)$ with the highest rank - full-time professor dedicated more than 20 years of service (62.1\%) (Table 2.).

Table 2. The distribution of the sample according to the years of service

\begin{tabular}{lcccc}
\hline Years of Service & $1-5$ & $5-10$ & $10-20$ & 20 or more \\
\hline Teaching Fellow & $40.3 \%$ & $40.3 \%$ & $17.7 \%$ & $1.6 \%$ \\
Assistant Professor & $6.1 \%$ & $28.8 \%$ & $62.1 \%$ & $3.0 \%$ \\
Associate Professor & -- & $6.5 \%$ & $41.9 \%$ & $51.6 \%$ \\
Professor & -- & -- & $21.2 \%$ & $78.8 \%$ \\
Other Ranks & 47.4 & 15.8 & 26.3 & $10.5 \%$ \\
\hline
\end{tabular}

Data collection and analysis. For the purposes of this research, a questionnaire was developed for teachers of higher education institutions, which contained closed and open-ended questions. In relation to the defined research questions and tasks the following was investigated: 1) teachers' access to ICT resources; 2) teachers' use of education technology, namely the specific ICT tools usage; 3) teachers' opportunities for participation in ICT training programs in the past five years; 4) participation in projects related to ICT application in teaching.

Data analysis comprised of both descriptive statistics and correlational testing. The descriptive statistical analysis included measures such as distribution, central tendency, and dispersion of data. An additional statistical procedure was performed, as well. Pearson's Correlation Coefficient (r) was used to measure the strength of the linear relationship between two selected study variables.

\section{RESULTS}

The overall study findings suggest positive trends in utilizing ICT in the Serbian higher education system. The obtained data was sufficient to provide comprehensive insights and understanding of the current practices, including possible future directions of instructional ICT development.

Concerning the first research question pertaining to the teachers' perception of access level to ICT resources within their educational institutions, the results indicate strong teacher dedication to the process of integrating learning technologies in the curricula across the variety of academic disciplines. Research findings show that the majority of teachers who took part in 
the survey reported that their need for the application of ICT in instruction is considerably high (42.7\%) and high (42.2\%). A minor percentage of faculty $(12.3 \%)$ reported an intermediate level of need, while $2.4 \%$ of respondents indicated a very low level, and only $0.5 \%$ reported that the application of ICT in education is not required. Undoubtedly the obtained data suggests that teachers recognize the potential of emerging instructional technologies in teaching and learning.

Furthermore, the findings indicate that teachers' access to different ICT resources at their institutions is rated as moderately high $(\mathrm{M}=3.85, \mathrm{SD}$ $=0.90$ ) on a five-point Likert scale. In their opinion, the availability of technical resources within the institution (especially computers and the Internet) is satisfactory, while the professional support is less accessible (Table 3).

Table 3. Teachers' Perception of Access to ICT Resources in Schools

\begin{tabular}{lll}
\hline ICT Resources & $\mathrm{M}$ & $\mathrm{SD}$ \\
\hline Computer & 4.76 & 0.62 \\
Internet & 4.77 & 0.59 \\
Printing Documents & 4.50 & 0.91 \\
Copying \& Scanning & 4.38 & 0.99 \\
Projector & 4.45 & 0.82 \\
CD \& DVD Players & 3.94 & 1.43 \\
Audio \& Video Equipment & 3.21 & 1.53 \\
Video-Conferencing Equipment & 2.29 & 1.43 \\
Web-hosting & 4.12 & 1.17 \\
Relevant Software Packages & 3.64 & 1.25 \\
Access to Academic Database & 3.94 & 1.11 \\
Technical Support & 3.76 & 1.17 \\
Pedagogical-Didactical Support & 2.93 & 1.45 \\
Professional Development - webinars & 2.57 & 1.34 \\
\hline Total: Level of Access to ICT Resources & 3.85 & 0.90 \\
\hline
\end{tabular}

The extent to which teachers apply different ICT tools and software packages in the classroom was the second research question addressed in this study. The obtained findings show that the use of different software solutions in teaching is at a mediocre level at best $(\mathrm{M}=2.65, \mathrm{SD}=1.00)$. Basic software packages, such as MS Office, have the highest applicability, with $70.1 \%$ of study respondents who regularly use this software in instruction, while all other applications are implemented to a much lesser extent (Table 4). 
Table 4. Teachers' Perception of the Intensity of Software Use in Teaching

\begin{tabular}{|c|c|c|c|c|c|}
\hline \multirow{2}{*}{ Software } & Never & Rarely & Sometimes & Often & Always \\
\hline & $\%$ & $\%$ & $\%$ & $\%$ & $\%$ \\
\hline $\begin{array}{l}\text { Basic Software Packages } \\
\text { (MS Office) }\end{array}$ & 1.9 & 0.9 & 5.2 & 28.1 & 70.1 \\
\hline $\begin{array}{l}\text { Learning Management } \\
\text { Systems (Moodle, } \\
\text { Blackboard) }\end{array}$ & 25.6 & 9.5 & 19.9 & 20.9 & 24.2 \\
\hline $\begin{array}{l}\text { Instant Messaging Tools } \\
\text { (Skype, Google Talk) }\end{array}$ & 32.7 & 17.1 & 20.4 & 15.2 & 14.7 \\
\hline $\begin{array}{l}\text { Social Networking Apps } \\
\text { (Facebook, Google Apps, } \\
\text { Ning) }\end{array}$ & 43.6 & 19.4 & 17.1 & 11.8 & 8.1 \\
\hline $\begin{array}{l}\text { Web development } \\
\text { platforms } \\
\text { (Blogger, Edublogs, } \\
\text { Wikispaces) }\end{array}$ & 51.2 & 21.8 & 16.1 & 8.1 & 2.8 \\
\hline $\begin{array}{l}\text { Programs for creating } \\
\text { and storing photos, audio } \\
\text { and video recording } \\
\text { (Flickr, iTunes, } \\
\text { YouTube) }\end{array}$ & 38.9 & 24.6 & 23.2 & 9.0 & 4.3 \\
\hline
\end{tabular}

Additionally, the study goal was to identify several aspects related to Professional Development (PD) in the area of ICT for teachers in a five-year period. The condensed findings are presented in Table 5. With regard to the perceived level of available PD opportunities, the obtained findings suggest that teachers claim to have had relatively limited opportunities to participate in professional development programs $(\mathrm{M}=2.21, \mathrm{SD}=1.25)$ in the last five years. The majority of teachers (37.9\%) reported that they never had the opportunity to participate in professional development programs, $29.4 \%$ rarely had the opportunity, $18 \%$ often, $10.4 \%$ sometimes, and only $4.3 \%$ of respondents consider that professional development opportunities are always available. On the other hand, the findings show that teachers' interest in professional development is relatively high $(\mathrm{M}=3.61, \mathrm{SD}=1.15)$ in comparison to perceived opportunities for participation.

When it comes to in-service training focused on the integration of ICT (e.g. computers) in teaching, $27.5 \%$ of respondents claim that they sometimes had the opportunity to receive in-service training in this field, almost the same number of teachers $(27 \%)$ believe that they never had that opportunity, $21.8 \%$ consider it rare, $18 \%$ often, and $5.7 \%$ of participants perceived that training opportunities are constantly present. 
Table 5. Teachers' Level of Interest in ICT Related Professional Development

\begin{tabular}{lcc}
\hline Professional Development & M & SD \\
\hline Level of Perceived PD Opportunities & 2.21 & 1.55 \\
Expressed Level of Personal Interests in PD & 3.61 & 1.51 \\
In-service Training focused on the Integration of ICT (computers) & 2.54 & 1.22 \\
in instruction & 3.65 & 1.15 \\
Training Focused on the integration of LMS in instruction & 3.38 & 1.14 \\
Training Cantered Around Topics within the area of Strategic & & \\
Management in ICT & \\
\hline
\end{tabular}

Intriguingly, a significant positive correlation was found between the teachers' age $(\mathrm{M}=3.26 \mathrm{SD}=1.28)$ and the overall perceived level of available opportunities for professional development $(\mathrm{M}=2.21 \mathrm{SD}=1.24), \mathrm{r}=.159, \mathrm{p}=$ $<.001, \mathrm{n}=211$. Thus, the results suggest that the higher perception of available opportunities for professional development is associated with seniority in general. However, the strength of the identified correlation is very weak.

Considering that teachers can acquire professional competence by participating in various institutional funded projects, the authors analyzed the number of projects involving the application of ICT in the classroom in which teachers participated in the last five years. Research findings indicate that the majority of respondents $(54.5 \%)$ reported involvement in one to three projects of this type, while on the other side of spectrum $7.1 \%$ of teachers stated that they participated in more than seven projects.

Finally, qualitative research findings based on open-ended questions about professional development procedures indicate that educational institutions, in accordance with higher education legislation, developed relevant policies for conducting research and monitoring employees' scientific and professional development. Four out of ten assessed institutions have established annual institutional quotas regarding teacher participation in conferences and scientific events. These institutions typically have advanced IT systems for tracing teachers' scientific accomplishments. On the other hand, institutions that did not adopt the advanced IT systems for monitoring scientific work make ad-hoc decisions regarding teacher participation in conferences, or this participation solely depends on personal initiative. Nevertheless, all institutions highly value teacher involvement in scientific events and projects, and they seek to allocate significant resources to support this type of professional engagement. Study findings also indicate that research projects often consist of groups of teachers and the research topics do not necessarily reflect the institutional policies and strategic orientations. 


\section{DISCUSSION}

Study findings suggest that the majority of respondents acknowledge the need for the integration of ICT in instruction at institutions of higher education. These results are reassuring, considering that the number of students that have Internet access in Serbia increased significantly in the period between 2009 and 2012 (OECD, 2015). This trend continues; therefore, it can be assumed that future students will expect online and digital education to be the norm rather than the exception or innovation.

On the other hand, distance education programs enable institutions of higher education to provide more accessible educational services, expand their capacity and enrollment, enter new markets and enhance overall quality (Alstete \& Beutell, 2004). This trend benefits students who might not otherwise be able to study due to financial challenges, lack of time, and spatial constraints (Šćepanović, Marjanović \& Radišić, 2016). In addition, this trend adds an international dimension to educational programs and research (Lawton et al., 2013).

Study respondents indicate that there is a solid basis for the instruction supported by basic hardware and software, while there are certain limitations regarding the integration of subject-related software packages. The higher education teachers recognized the need for additional professional support and development in this area. The study results suggest that teachers perceive the IT infrastructure in institutions as a more dominant or essential factor that shapes instructional activities than the use of available software tools in instruction. A possible explanation for this finding is the lack of professional skills and a low level of teacher expertise and software proficiency. The results also demonstrate that the majority of teachers consider that there are limited opportunities for professional development in the area of educational ICT. However, it is worth noting that professional development for educational technology is essential, and it is reinforced by a body of research (OECD, 2015; Š́cepanović, Marjanović i Radišić, 2016) which argues that a higher level of professional competencies is critical for student learning outcomes. Findings of other studies suggest that there are a number of investments in ICT that have failed and/or were unsustainable since those investments were made into the computer equipment (that was rarely or not used, and quickly became out of date) and software development (learning platforms) without previously planned and assured teacher training for its use (Centre for Educational Research and Innovation, 2001; Balazs, 2017).

Favorable results related to the participants' interest for professional development are more than evident. Namely, teacher interest in professional development is higher than their assessment of available opportunities for participation in these programs. This finding is strongly reassuring as it may indicate respondents' positive attitude toward professional development despite the fact that they lack financial resources to meet the increasingly complex demands placed on them. Empirical studies (Balazs, 2017; Cepni, Tas \& 
Kose, 2006) conducted in the educational systems of countries in the region show similar trends.

Concerning the teachers' needs for professional development in the area of educational ICT, the study results indicate that more than half of the study respondents recognize the necessity for conducting professional development trainings focused on smart board technology. One-third of the study participants pointed out the need for training centered around LMS and web development platforms. Finally, the overall research findings suggest that university teachers need comprehensive support for the implementation of ICT in teaching in order to maximize the affordances of the existing ICT infrastructure in higher education institutions in the Republic of Serbia.

\section{CONCLUSION}

The increasing number of ICT devices and tools and their availability to students and teachers open up a multitude of opportunities in higher education. However, at the same time, they introduce new challenges that need an adequate response. To make the use of ICT in higher education a success requires a balanced approach between the acquisition of hardware, permanent technical support and support focused on developing teachers' digital skills and competencies through professional development programs.

The overall study findings call for a profound change in the application of ICT in instruction, in a way which emphasizes the planning process which implies a re-thinking of and setting clear goals and objectives, rather than merely focusing on the usage of diverse ICT tools (High Level Group on the Modernisation of Higher Education, 2013). What is currently missing is a comprehensive strategic document that would address the needs in higher education for further enhancement of the available academic capacities and infrastructure development. This document should also address current needs, define specific measures and activities within different geographical regions and scientific fields as well as in each of the areas of educational policy (e.g. curriculum development, leadership and governance, professional development). Educational technology might have a more substantial impact if the policies and programs concerning the application of ICT in education are conducted as coordinated support of a change of all components of the educational systems (UNESCO, 2011).

\section{REFERENCES}

Aloraini, S. (2012). The impact of using multimedia on students' academic achievement in the College of Education at King Saud University. Journal of King Saud University-Languages and Translation, 24(2), 75-82.

Alstete, J. \& Beutell, N. (2004). Performance indicators in online distance learning courses: a study of management education. Qual. Assur. Educ., 2 (1), 6-14. 
Balazs, P. (2017). Online Educational Environments and ICT Tools in Higher Education: Teacher Survey. Andragoške studije, 1, 145-181.

Centre for Educational Research and Innovation. (2001). E-learning: The partnership challenge. Paris, FR: OECD Publishing.

Cepni, S., Tas, E., \& Kose, S. (2006). The effects of computer-assisted material on students' cognitive levels, misconceptions and attitudestowards science. Computers and Education, 46(2), 192-205.

Cairncross, S. \& Mannion, M. (2001). Interactive Multimedia and Learning: Realizing the Benefits. Innovations in Education and Teaching International, 38(2), 156-164.

Commission of the European Communities (2008). The use of ICT to support innovation and lifelong learning for all - A report on progress (SEC (2008) 2629 final). Brussels, BE: Directorate General Education and Culture.

Retrieved: January 26, 2017 from the World Wide Web http://www.europarl.europa. eu/registre/docs_autres_institutions/commission_europeenne/sec/2008/2629/C OM_SEC(2008)2629_EN.pdf

European Commission (2010). Europe 2020: A strategy for smart, sustainable and inclusive growth. Communication from the Commission (COM (2010) 2020). Brussels, BE: European Commission. Retrieved: January 26, 2017 from the World Wide Web http://ec.europa.eu/eu2020/pdf.

European Commission (2013). Opening up Education: Innovative teaching and learning for all through new Technologies and Open Educational Resources. Communication from the Commission to the European Parliament, the Council, the European Economic and Social Committee and the Committee of the Regions (COM (2013) 654 final). Brussels, BE: European Commission. Retrieved: January 26, 2017 from the World Wide Web http://eurlex.europa.eu/legal-content.

Ferrari, A. (2013). DIGCOMP: A Framework for Developing and Understanding Digital Competence in Europe. Luxembourg: European Commission. Joint Research Centre.

Haggard, S., Gore, T., Inkelaar, T., Brown, S., Mills, R., Tait, A., Angulo, T. (2013). The Maturing of the MOOC: Literature review of massive open online courses and other forms of online distance learning (BIS research paper number 130). London, UK: Department for Business, Innovation and Skills. Retrieved from January 26, 2017 https://www.gov.uk/government/uploads/system/uploads/ attachment_data/file/240193/13-1173-maturing-of-the-mooc.pdf.

High Level Group on the Modernisation of Higher Education. (2013). Report to the European Commission on improving the quality of teaching and learning in Europe's higher education institutions. Luxembourg, LU: Publications Office of the European Union. Retrieved January 26, 2018 from the World Wide Web http://ec.europa.eu/education/library/reports/modernisation_en.pdf

Lawton, W., Ahmed, M., Angulo, T., Axel-Berg, A., Burrows, A., \& Katsomitros, A. (2013). Horizon scanning: What will Higher Education look like in 2020? London, UK: The UK HE International Unit and Leadership Foundation for Higher Education.

Mayer, E. R. (2017): Using multimedia for e-learning. Journal of Computer Assisted Learning, 33, 403-423.

Moreno, R., \& Mayer, R. E. (2000a). A coherence effect inmultimedia learning: The case for minimizing irrelevantsounds in the design of multimedia messages. Journal ofEducational Psychology, 92, 117-125. 
Moreno, R., \& Mayer, R. E. (2000b). Engaging students inactive learning: The case for personalized multimediamessages. Journal of Educational Psychology, 92, $724-733$.

OECD (2015). Students, computers and learning: Making the connection. Paris, FR: OECD Publishing.

Pantić, N. \& T. Wubbels (2010). Teacher competencies as a basis for teacher education:views of Serbian teachers and teacher educators. Teaching and Teacher Education, 26, 694-703.

Šćepanović, D. (2016). Strateško upravljanje projektom razvoja i implementacije savremenih obrazovnih tehnologija u ustanovama visokog obrazovanja [Strategic Project Management for a Development and Implementation of the Education Technology in Higher Education Institutions], doktorska disertacija, Fakultet organizacionih nauka, Univerzitet u Beogradu.

Šćepanović D., Marjanović U., Radišić J. (2016). Digitalno i onlajn učenje u Srbiji: visoko obrazovanje, [Digital and Online Learning in Serbija: Higher Education] U Katić, V. (ur): Zbornik radova XXII skupa Trendovi razvoja Nove tehnologije u nastavi (str. 84-87). Novi Sad: Fakultet tehničkih nauka.

The European Parliament and the Council of the European Union (2006) Recommendation of the European Parliament and of the Council of 18 December 2006 on key competences for lifelong learning. Official Journal of the European Union, L394/10.

Retrieved January 26, 2018 from the World Wide Web http://bit.ly/24rCITS

UNESCO (2011). Transforming education: The power of ICT policies. Paris, FR: UNESCO. Retrieved: January 26, 2018 from the World Wide Web http://unesdoc.unesco.org/images/0021/002118/211842e.pdf

\title{
СПРЕМНОСТ НАСТАВНИКА ЗА ПРИМЕНУ ИНФОРМАЦИОНО-КОМУНИКАЦИОНИХ ТЕХНОЛОГИЈА У ИНСТИТУЦИЈАМА ВИСОКОГ ОБРАЗОВАҢА
}

\author{
Данијела Шћепановић ${ }^{1}$, Исидора Кораћ ${ }^{2}$, Бојан Лазаревић ${ }^{3}$ \\ ${ }^{1}$ Министарство просвете, науке и технолошког развоја, Београд, Србија \\ ${ }^{2}$ Висока школа струковних студија за васпитаче и пословне информатичаре \\ „Сирмиум”, Сремска Митровица, Република Србија \\ ${ }^{3}$ Универзитет у Флориди, Колеџ за образовање, Гејнсвил, Флорида, САД
}

\section{Резиме}

Развој информационо-комуникационих технологија (ИКТ) и повећан обим услуга у области отвореног онлајн-образовања нуде низ могућности, али и представљају изазов за високо образовање. Ефикасна примена ИКТ у настави подразумева не само обезбеђивање потребне рачунарске опреме већ и испитивање потреба корисника, континуирану техничку подршку и одређене компетенције наставника. Бројни званични документи из области образовања који се баве анализом начина на које се ИКТ примењује у наставној пракси указују на недостатак дигиталних компетенција наставника. Да би успешно применио ИКТ у настави, наставник треба да влада основним рачунарским апликацијама (обрада текста, 
табела, базе података, складиштење и руковање информацијама), да уме да креира подстицајно онлајн-окружење за учење, да примењује ИКТ за сарадњу, умрежавање и колаборативно учење са колегама.

У раду се разматрају различити ставови наставника у вези са применом ИКТ-а у настави у установама високог образовања, као и потребе за стручним усавршавањем у овој области. Разматрају се следећа истраживачка питања: 1) Како наставници процењују приступ ИКТ ресурсима у оквиру њихове образовне установе?; 2) Коју образовну технологију и софтвер наставници користе током наставе?; 3) Како наставници процењују свој професионални развој и учешће у развојним ИКТ пројектима?

У истраживању је учествовало 211 наставника запослених у установама високог образовања на универзитетима у Београду, Новом Саду, Крагујевцу, Новом Пазару и Нишу. У складу са сврхом истраживања, осмишљен је упитник са питањима отвореног и затвореног типа.

Налази истраживања указују на то да наставници препознају потребу примене ИКТ-а у наставном процесу, док је њихова процена приступа ИКТ наставним материјалима различита, у зависности од приступа технологији и ИКТ услугама. Утврђено је да је ниво практичне примене ИКТ-а у учионици и даље осредњи или релативно низак. Када је у питању употреба софтверских решења у настави, налази указују на то да преовладава примена основних софтверских решења као што је MS Office, а потом примена система за управљање учењем. Резултати несумњиво показују да су испитаници заинтересовани за професионални развој. Тачније, заинтересованост наставника за професионални развој виша је од њихове процене о постојању прилика да учествују у овим програмима.

У закључним разматрањима указује се на потребу израде свеобухватног стратешког документа који би одговарао потребама високог образовања за даљу изградњу инфраструктуре, институционалних и професионалних капацитета, као и низ мера у области осигурања квалитета онлајн-образовања. 